\title{
Lichenized fungi of a chestnut grove in Livari (Rumija, Montenegro)
}

\author{
Helmut Mayrhofer $^{1 *}$, Anton Drescher ${ }^{1}$, DaniJela Stešević ${ }^{2}$, \\ PETER O. BILOVITZ ${ }^{1}$ \\ ${ }^{1}$ Institute of Plant Sciences, Karl-Franzens-University Graz, Holteigasse 6, \\ 8010 Graz, Austria \\ ${ }^{2}$ Faculty of Natural Sciences and Mathematics, University of Montenegro, \\ Džordža Vašingtona bb, 81000 Podgorica, Montenegro
}

\begin{abstract}
Sixty taxa (59 species and 1 variety) of lichenized fungi are reported from a chestnut grove in Livari. The majority of them (55 species and 1 variety) occurred on Castanea sativa. The recently described Xylographa soralifera is new to the Balkan Peninsula. The lichenicolous fungus Monodictys epilepraria growing on Lepraria rigidula is new to Montenegro. The lichen mycota is compared with similar localities in Italy and Switzerland. The species composition in Livari is most similar to the Montieri site in Tuscany.
\end{abstract}

Key words: biodiversity, Castanea sativa, lichenized Ascomycota, Montenegro

\section{Introduction}

Cultivated Castanea sativa groves are unique because of their size and long-term continuous exploitation. Sweet chestnut is very common in the Mediterranean basin and the bordering sub-Mediterranean region. Chestnut fruits are an important source of food for humans and domestic animals (GONDARD et al. 2006). The lichenized fungi of chestnut groves has been assessed in two regions of Switzerland, Bergell (ROTH and SCHEIDEGGER 1997) and Chestenenweid at Lake Lucerne (DIETRICH and BÜRGI-MEYER 2011) and in the Italian regions of Piedmont (MATteucCi et al. 2010), the Western Alps to the Northern Apennines (MATTEUCCI et al. 2012), Tuscany (LoPPI et al. 1997), and the island of Elba (LinDACHER and PiETsChmann 1990). Castanea sativa trees as phorophytes have been used in monitoring studies dealing with hydrogen sulphide impact on lichen mycota (LOPPI and NASCIMBENE 1998, TRETIACH and GANIS 1999) and with trace elements (LoPPI and Bonini 2000) in Tuscany. In Liguria, GIORDANI (2007) and GIORDANI et al. (2009) have used Castanea sativa among other trees for different approaches in biomonitoring. Taking into consideration only

\footnotetext{
* Corresponding author, e-mail: helmut.mayrhofer@uni-graz.at Copyright $^{\circledR} 2013$ by Acta Botanica Croatica, the Faculty of Science, University of Zagreb. All rights reserved.
} 
Mayrhofer H., Drescher A., SteŠEvić D., Bilovitz P. O.

Castanea sativa and Quercus ssp. GIORDANI (2012) assessed the effects of forest management on epiphytic lichens in coppiced forests in humid Mediterranean Liguria. APRILE et al. (2011) reported on monitoring of air pollution in relation to land use patterns in the Campania region of Italy using Castanea sativa and Quercus pubescens as phorophytes.

The knowledge of the lichen biota of Montenegro has improved because of extensive field work in Biogradska Gora National Park (BILOviTz et al. 2009) and at other sites (BILOVITZ et al. 2008, 2010). KNEŽEVIĆ and MAYRHOFER (2009) have provided a catalogue based on a comprehensive evaluation of published sources.

This paper contributes a new lichen species (Xylographa soralifera) for the Balkan Peninsula, a new lichenicolous fungus (Monodictys epilepraria) for Montenegro and new distribution data for the interesting species Caloplaca monacensis, Collema subflaccidum and Fuscopannaria mediterranea. The species composition is compared with a site in Switzerland (Bergell), sites in Piedmont, Tuscany and the island of Elba (Tab. 1).

Tab. 1. List of taxa from Livari in comparison with the sites in Tuscany (T), Elba (E) and Piedmont (P) in Italy, Bergell (B) in Switzerland and from various sites in the Western Alps and Northern Apennines (L) of Italy. * - Species occurring only on Morus alba $;^{\circ}$ - as Lecidella elaeochroma.

\begin{tabular}{|c|c|c|c|c|c|}
\hline Taxa & $\mathrm{T}$ & $\mathrm{E}$ & $\mathrm{P}$ & $\mathrm{B}$ & $\mathrm{L}$ \\
\hline Amandinea punctata (Hoffm.) Coppins et Scheid. & $\mathrm{X}$ & & $\mathrm{X}$ & $\mathrm{X}$ & $\mathrm{X}$ \\
\hline Arthonia radiata (Pers.) Ach. & $\mathrm{X}$ & & $\mathrm{X}$ & $\mathrm{X}$ & $\mathrm{X}$ \\
\hline Caloplaca herbidella (Hue) H. Magn. & & & & $\mathrm{X}$ & $\mathrm{X}$ \\
\hline \multicolumn{6}{|l|}{ *Caloplaca monacensis (Leder.) Lettau } \\
\hline *Candelariella reflexa (Nyl.) Lettau & $\mathrm{X}$ & & $\mathrm{X}$ & $\mathrm{X}$ & \\
\hline Cladonia coniocraea (Flörke) Spreng. & $\mathrm{X}$ & & $\mathrm{X}$ & $X$ & $\mathrm{X}$ \\
\hline Cladonia pyxidata (L.) Hoffm. & $X$ & & & & \\
\hline Collema flaccidum (Ach.) Ach. & & & & & $\mathrm{X}$ \\
\hline Collema subflaccidum Degel. & & & & & $\mathrm{X}$ \\
\hline Degelia plumbea (Lightf.) P. M. Jørg. et P. James & $\mathrm{X}$ & $\mathrm{X}$ & & & $\mathrm{X}$ \\
\hline Flavoparmelia caperata (L.) Hale & $\mathrm{X}$ & $X$ & $\mathrm{X}$ & $X$ & $\mathrm{X}$ \\
\hline Fuscopannaria mediterranea (C. Tav.) P. M. Jørg. (see Fig. 4) & & & & & $\mathrm{X}$ \\
\hline Hypocenomyce scalaris (Ach.) M. Choisy & & & $\mathrm{X}$ & $X$ & $\mathrm{X}$ \\
\hline Hypogymnia tubulosa (Schaer.) Hav. & & & & $X$ & \\
\hline Lecanora chlarotera Nyl. & $\mathrm{X}$ & & $\mathrm{X}$ & $\mathrm{X}$ & $\mathrm{X}$ \\
\hline Lecidella achristotera (Nyl.) Hertel et Leuckert & $\mathrm{X}$ & $\mathrm{X}$ & $\mathrm{X}$ & $X$ & $\mathrm{X}$ \\
\hline \multicolumn{6}{|l|}{ Lepraria leuckertiana (Zedda) L. Saag } \\
\hline Lepraria rigidula (de Lesd.) Tønsberg & & & & $\mathrm{X}$ & \\
\hline Lepraria vouauxii (Hue) R. C. Harris & & & & $\mathrm{X}$ & \\
\hline Leptogium lichenoides (L.) Zahlbr. & & $\mathrm{X}$ & & & $\mathrm{X}$ \\
\hline Leptogium saturninum (Dicks.) Nyl. & & & & $\mathrm{X}$ & \\
\hline Leptogium teretiusculum (Wallr.) Arnold & & & & & \\
\hline
\end{tabular}


Tab. 1. - continued

\begin{tabular}{lccccc}
\hline Taxa & T & E & P & B & L \\
\hline Lobaria amplissima (Scop.) Forssell & X & & & & X \\
Lobaria pulmonaria (L.) Hoffm. & X & X & & X & X \\
$\begin{array}{l}\text { Lobarina scrobiculata (Scop.) Nyl. ex Cromb. } \\
\text { Megalospora tuberculosa (Fée) Sipman }\end{array}$ & & & & & X \\
Melanelixia fuliginosa (Duby) O. Blanco et al. & & & & & \\
Melanelixia glabra (Schaer.) O. Blanco et al. & & & X & X & X \\
Melanohalea exasperata (De Not) O. Blanco et al. & & & & &
\end{tabular}

Micarea prasina Fr. (on lignum of root)

Nephroma laevigatum Ach.

Ochrolechia androgyna (Hoffm.) Arnold

Pachyphiale carneola (Ach.) Arnold

$\mathrm{X}$

Parmelia saxatilis (L.) Ach.

Parmelia sulcata Taylor

$\begin{array}{lllll}X & & X & X & X \\ X & X & X & X & X\end{array}$

Parmeliella triptophylla (Ach.) Müll. Arg.

Parmelina quercina (Willd.) Hale

Parmelina tiliacea (Hoffm.) Hale

Parmeliopsis ambigua (Wulfen) Nyl.

Peltigera collina (Ach.) Schrad.

Peltigera praetextata (Flörke ex Sommerf.) Zopf

Pertusaria albescens (Huds.) M. Choisy var. albescens

Pertusaria albescens var. corallina auct.

Pertusaria coccodes (Ach.) Nyl.

Pertusaria flavida (DC.) J. R. Laundon

Pertusaria hymenea (Ach.) Schaer.

Pertusaria leioplaca DC.

$\begin{array}{llll} & & X & X \\ X & X & X & X \\ & & X & X\end{array}$

Pertusaria pertusa (Weigel) Tuck.

Phaeophyscia chloantha (Ach.) Moberg

*Phaeophyscia orbicularis (Neck.) Moberg

Phlyctis argena (Spreng.) Flot.

Physconia perisidiosa (Erichsen) Moberg

Physconia venusta (Ach.) Poelt

$\begin{array}{lllll}X & X & & & \\ X & X & X & X & X\end{array}$

Placynthiella icmalea (Ach.) Coppins et James

*Punctelia subrudecta (Nyl.) Krog

Ramalina farinacea (L.) Ach.

$\begin{array}{lllll} & & & \text { X } & \text { X } \\ X & & & X & \text { X } \\ X & X & & & \text { X } \\ X & X & X & & \text { X } \\ \text { X } & \text { X } & & & \text { X }\end{array}$

Rinodina sophodes (Ach.) A. Massal.

$\begin{array}{llll} & X & X & X \\ X & X & X & X \\ & X & & X\end{array}$

$\mathrm{X}$

Strigula affinis (A. Massal.) R. C. Harris (on lignum)

$\begin{array}{llll} & & X & \\ & X & X & X \\ X & X & & X \\ X & X & & X\end{array}$

Trapeliopsis flexuosa (Fr.) Coppins et P. James (on lignum)

Xylographa soralifera Holien et Tønsberg (on lignum) 
Mayrhofer H., Drescher A., SteŠEvić D., Bilovitz P. O.

\section{Study area - physical settings}

The investigated locality on the eastern slopes of the Rumija mountain range is situated in the small rural settlement called Gornja Briska (coordinates $42^{\circ} 06$ ' 58-59' $\mathrm{N} / 19^{\circ} 13^{\prime}$ $16-18$ "E) c. $1.5 \mathrm{~km}$ southeast of the village of Livari at an elevation of 475-490 m above sea level (Fig. 1). The Rumija range stretches in the NW-SE direction, forming a natural barrier between the Adriatic Sea and Lake Skutari. In contrast to the steep slopes facing the Adriatic Sea, the eastern slopes facing Skutari Lake are discontinued by plateaus, mainly in the southern part.

The regional climatic situation is characterized by the climatic diagrams from the two nearby stations Virpazar at the northwestern lakeside and Shkodra (Albania) at the southeastern shore of Lake Skutari (Fig. 3). The sub-Mediterranean (supra-Mediterranean) character is expressed by the precipitation curve with a maximum in October and a very indistinct second peak in May (station Shkodra, FurLAN 1977). The mean dry period in summer (dotted polygon in the diagram with the precipitation curve below the temperature line) lasts less than two months. This character is not only altered by the geomorphological situation on a plateau, but also by the water storage capacity of the deep soil, which mitigates the dry period during the summer months (FURLAN 1977).

These conditions enable the development of deciduous broadleaved forests in this altitudinal belt: in general a coppiced forest of white hornbeam (Carpinion orientalis alliance Horvat 1958), mixed forests with oak and chestnut (Castaneo-Quercetum submediterraneum Wraber 1954) and chestnut plantations.

The open structure of the chestnut stands (Fig. 2) originates from plantation for crop production and results in a rather irregular canopy.

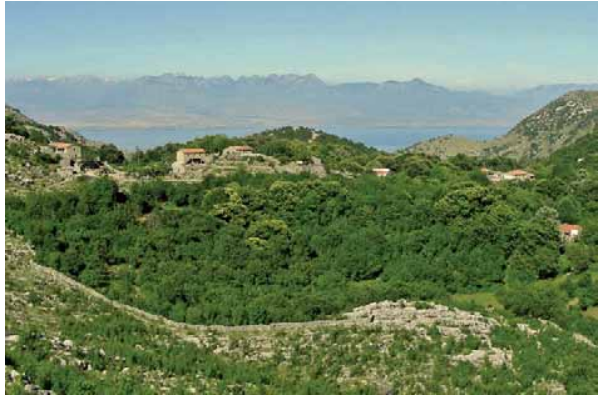

Fig. 1. The investigated locality is situated in the small rural settlement called Gornja Briska, $1.5 \mathrm{~km}$ southeast of the village Livari. Background: Lake Skutari and Albanian Alps.

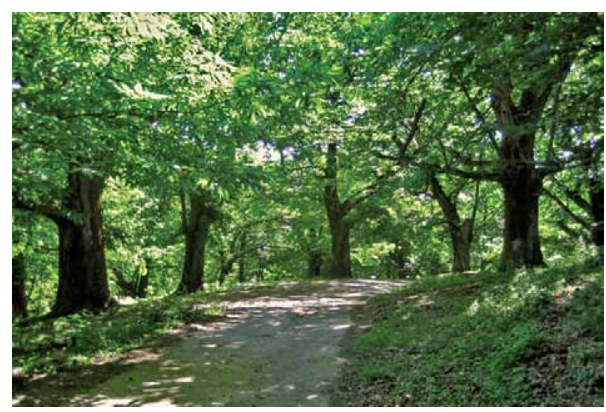

Fig. 2. The open structure of the chestnut stands originates from plantation for crop production and results in a rather irregular canopy.

\section{Material and methods}

Field studies were carried out in an old Castanea sativa grove on a slope flattening. About 40 trunks of Castanea sativa rich in species abundance and diversity were randomly selected and investigated. Some remarkable species were taken from one single trunk of a 

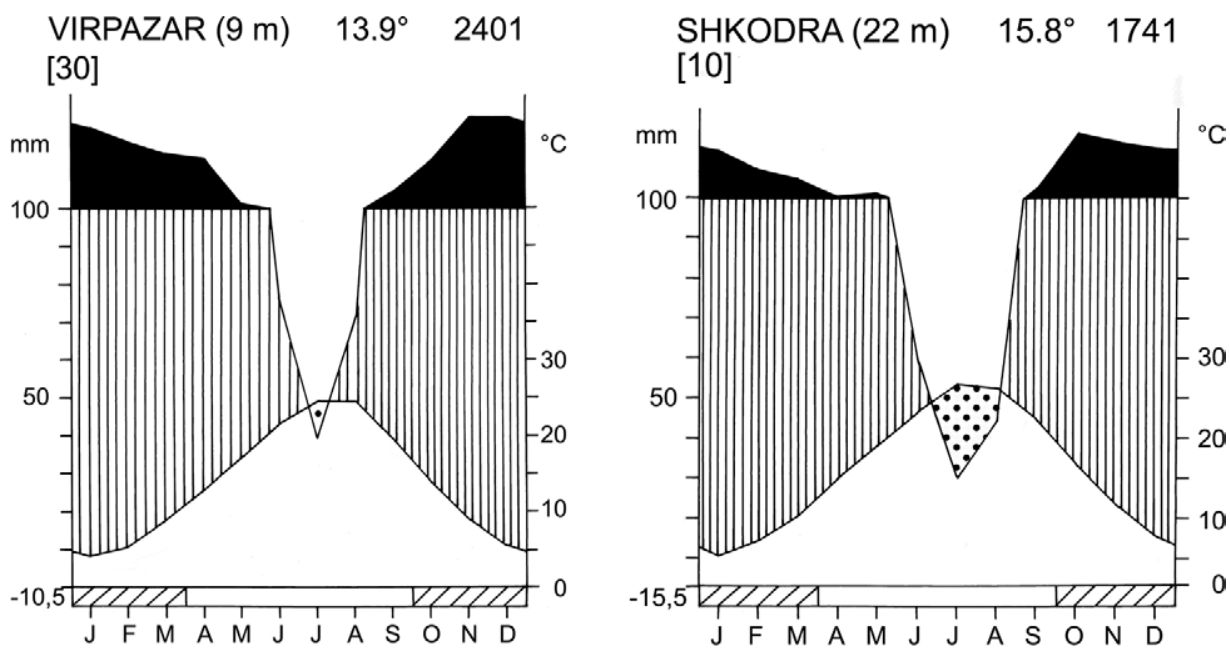

Fig. 3. Climatic diagrams from the two nearby stations Virpazar at the northwestern lakeside (data from the Hydrometeorological Institute of Montenegro) and Shkodra (Albania) at the southeastern shore (data from FURLAN 1977).

roadside Morus alba. The list presented is based on collections made by the first author in 2004 and supplemented with studies by the first and second author in 2009. The specimens have been identified with the aid of PoElT (1969), PoElT and VĚZDA (1977, 1981), Clauzade and Roux (1985) and WiRTH (1995). Some of the identifications required verification using standardized thin-layer chromatography (TLC) following the protocols of

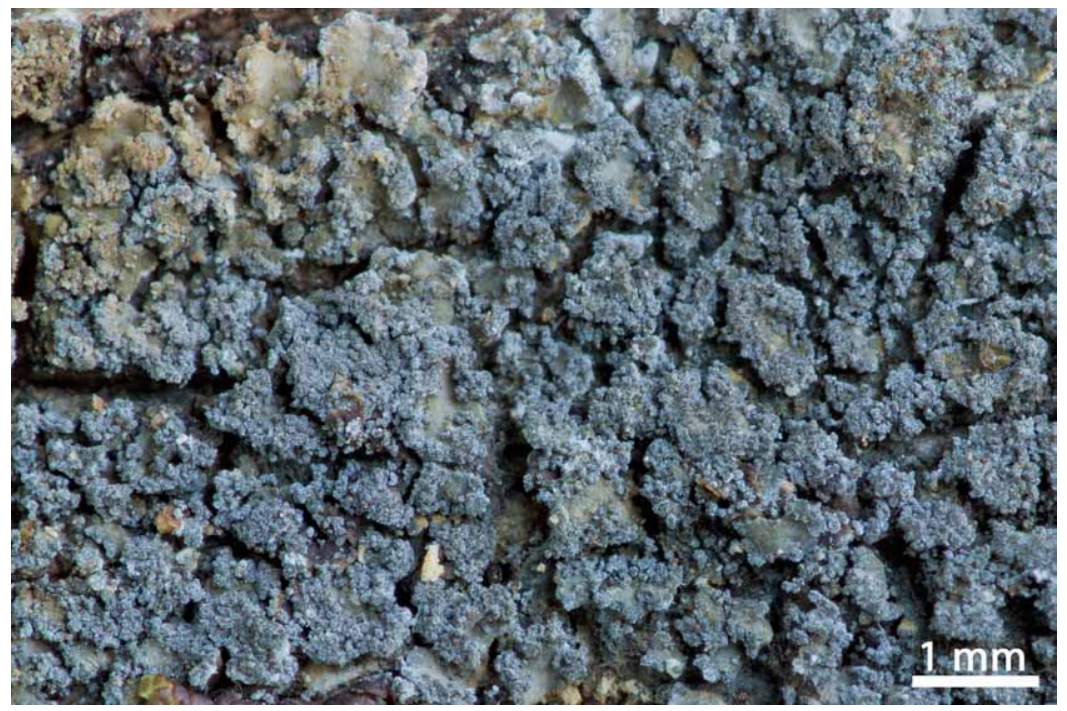

Fig. 4. Fuscopannaria mediterranea (Mayrhofer 18438; photo P. O. Bilovitz), a species rare in Montenegro. 
Mayrhofer H., Drescher A., SteŠEvić D., Bilovitz P. O.

White and JAMES (1985) and ORANGE et al. (2010). The specimens are preserved in the herbarium of the Institute of Plant Sciences, Karl-Franzens-University Graz (GZU). The nomenclature follows NIMIS and MARTELLOS (2008) and other modern treatments.

\section{Results}

Fifty nine species and one variety of lichenized fungi and the lichenicolous fungus Monodictys epilepraria are recorded (Tab. 1). Below we give remarks on the noteworthy species Caloplaca monacensis, Collema subflaccidum, Fuscopannaria mediterranea, Xylographa soralifera and Monodictys epilepraria:

Caloplaca monacensis is a neglected name for Caloplaca cerina var. cyanolepra (VONDRÁK et al. 2009). It is also known from two localities around Pljevlja in Northern Montenegro occurring on Pyrus communis and Fraxinus excelsior (BILOVITZ et al. 2010). Further records from the Balkan Peninsula are summarized by Аввотт (2009) for Greece, Bilovitz and MAYrhofer (2011) for Bosnia and Herzegovina, KušAn (1953) for Croatia and SuPPAN et al. (2000) for the Dinaric region of Slovenia. The species is also reported by VONDRÁK et al. (2009) and Šoun et al. (2011) from Bulgaria.

Collema subflaccidum was only known from the Adriatic coast from the surroundings of Herceg Novi (Degelius 1954, as Collema subfurvum) and Petrovac (VĚZDA 1968, as Collema furfuraceum; VĚZDA 1971, as Collema subfurvum). VĚZDA (1971) corrected his record of Collema furfuraceum published in VĚZDA (1968) as C. subfurvum. KNEŽEVIĆ and MAYRHOFER (2009) did not consider this correction and filled the first citation under Collema furfuraceum.

Fuscopannaria mediterranea (Fig. 4) was also only known from the environs of Herceg Novi (JøRGENSEN 1978, as Pannaria mediterranea) and Budva (BILOviTZ et al. 2008) at the Adriatic coast.

Xylographa soralifera was described from North America by HOLIEN and TøNSBERG (2008). They cited one record from Italy. HEININGER and SPRIBILLE (2009) recorded it from several localities in Austria and also a second specimen from Italy. The sample from Livari is unusually richly fertile with only few soralia.

Monodictys epilepraria Diederich et M. S. Christ. is a lichenicolous fungus on Lepraria rigidula. This is the first record from Montenegro of the species recently described by KuKWA and DiedERICH (2005). They report it from the Czech Republic, Great Britain, Lithuania, Poland, Spain and Sweden. Subsequently it was also mentioned from Estonia (SuIJA et al. 2006), Austria (HAFELlNER and OBERMAYER 2007), Slovenia (KuKwa 2008, BiLOvitz et al. 2011), Germany (Brackel 2009, Eichler et al. 2010, SCHIEFELbein 2013) and Bosnia and Herzegovina (BILOVITZ and MAYRHOFER 2010).

\section{Discussion}

RoTH and SCHEIDEGGER (1997) reported 111 species from 95 investigated trunks distributed within an area of c. $2 \mathrm{~km}^{2}$ of the region of Bergell in Switzerland. DiETRICH and BÜRGI-MEYER (2011) mentioned 77 epiphytic lichens including 38 species occurring on the trunks and twigs of Castanea sativa from one site in the canton of Lucerne in Central Switzerland. Castanea sativa was the best substrate followed by Quercus sp. with 34 species in 
their study area. MATTEUCCI et al. (2012) investigated 67 plots in orchards and coppices of Castanea sativa in three bioclimatic regions in the Western Alps and Northern Apennines of Italy, where they recorded 152 taxa. Temperate oceanic plots with high precipitation host species of the Lobarion communities in this area. LopPI et al. (1997) recorded 76 taxa from Montieri in Tuscany, while MATTEUCCI et al. (2010) reported 63 species from 77 trees including sixty-three Castanea sativa ones at four sites in Piedmont. The diversity in Livari (60 taxa) is similar. The species composition is most similar to the Tuscany site with species of the Lobarion, but Parmeliella triptophylla and Peltigera collina occur only in Livari. Lignicolous species like Micarea prasina, Strigula affinis or Trapeliopsis flexuosa are not considered in the cited papers from Italy and Switzerland. Medium aged trees with a diameter at breast height of 40 to $60 \mathrm{~cm}$ host the highest number of species in Livari, whereas the oldest and thickest trees with extremely deeply incised bark host hardly any lichen species. Moderate disturbance does not damage the lichens and most of them respond positively to increased light availability.

Eight species from Livari are mentioned in the red list of epiphytic lichens of Italy (NASCIMBENE et al. 2013): Megalospora tuberculosa as »critically endangered «, Caloplaca herbidella, Degelia plumbea, Lobaria amplissima, Lobarina scrobiculata, Pachyphiale carneola and Parmeliella triptophylla as »near threatened « as well as Lobaria pulmonaria as »least concern «. WIRTH (2010) introduced a procedure to assess the eco-climatic oceanity (KO) with the help of the two indicator values of continentality and moisture. According to this procedure the chestnut grove in Livari harbors a lot of species colonizing highly oceanic (KO 7) and extremely oceanic (KO 8-9) localities. Caloplaca herbidella, Leptogium saturninum, Lobarina scrobiculata and Rinodina sophodes are included in the category KO 7 , Degelia plumbea, Lobaria amplissima and Parmeliella triptophylla in the category $\mathrm{KO}$ 8-9. Nephroma laevigatum and Peltigera collina are between these two categories. On the other hand we did not find any lichen species of the categories KO 1-2 (colonizing extremely continental localities) and KO 3 (colonizing highly continental localities). The arithmetic mean of all species with regard to eco-climatic oceanity comes to 5 (KO $5=$ colonizing moderately oceanic localities).

\section{Acknowledgements}

We would like to thank Peter Kosnik for his technical support with TLC, Pramodchandra Harvey for valuable linguistic suggestions, Toby Spribille for the determination of Xylographa soralifera, Branka Knežević, Bojana Nedović, Danka Petrović, Miladin Jakić for their assistance during the field work and the Hydrometeorological Institute of Montenegro for supplying climate data. Financial support from the World University Service (WUS) Austria and from the Austrian Science Foundation (FWF project P20842-B16) is gratefully acknowledged by H.M. and P.O.B.

\section{References}

Аввотт, В. F. M., 2009: Checklist of the lichens and lichenicolous fungi of Greece. Bibliotheca Lichenologica 103, 1-368.

Aprile, G. G., Catalano, I., Migliozzi, A., Mingo, A., 2011: Monitoring epiphytic lichen biodiversity to detect environmental quality and air pollution: The case study of 
Mayrhofer H., Drescher A., SteŠEvić D., Bilovitz P. O.

Roccamonfina Park (Campania Region - Italy). In: Moldoveanu, A. M. (ed.), Air pollution - new developments, 227-244. InTech, Rijeka.

Bilovitz, P. O., BAtič, F., MAYrhofer, H., 2011: Epiphytic lichen mycota of the virgin forest reserve Rajhenavski Rog (Slovenia). Herzogia 24, 315-324.

Bilovitz, P. O., KnežEvić, B., SteŠEvić, D., Mayrhofer, H., 2009: Lichenized and lichenicolous fungi from Bjelasica (Montenegro) with special emphasis on the Biogradska Gora National Park. Bibliotheca Lichenologica 99, 67-80.

Bilovitz, P. O., Knežević, B., Stešević, D., Vitikainen, O., Dragićević, S., Mayrhofer, H., 2008: New or otherwise interesting lichenized and lichenicolous fungi from Montenegro. Fritschiana 62, 1-44.

Bilovitz, P. O., Mayrhofer, H., 2010: Lichenized and lichenicolous fungi from the Sutjeska National Park (Bosnia and Herzegovina), with special emphasis on the virgin forest reserve Perućica. Bibliotheca Lichenologica 104, 65-76.

Bilovitz, P. O., MaYrhofer, H., 2011: Catalogue of the lichenized and lichenicolous fungi of Bosnia and Herzegovina. Phyton 51, 1-67.

Bilovitz, P. O., SteŠEvić, D., Mayrhofer, H., 2010: Epiphytic lichens and lichenicolous fungi from the northern part of Montenegro. Herzogia 23, 249-256.

BRACKEL, W. v., 2009: Weitere Funde von flechtenbewohnenden Pilzen in Bayern - Beitrag zu einer Checkliste IV. Berichte der Bayerischen Botanischen Gesellschaft 66/67, 97-113.

Clauzade, G., Roux, C., 1985: Likenoj de okcidenta Eǔropo. Ilustrita determinlibro. Bulletin de la Société Botanique du Centre-Ouest, Nouvelle Série 7, 1-893.

Degelius, G., 1954: The lichen genus Collema in Europe. Morphology, taxonomy, ecology. Symbolae Botanicae Upsalienses 13, 1-499 + 27 plates.

DieTrich, M., BÜrgI-MeYer, K., 2011: Die Chestenenweid am Vierwaldstättersee (Kanton Luzern, Zentralschweiz) - ein bedeutender Lebensraum für Flechten trockenwarmer Standorte auf der Alpennordseite. Herzogia 24, 33-52.

Eichler, M., Cezanne, R., Teuber, D., 2010: Ergänzungen zur Liste der Flechten und flechtenbewohnenden Pilze Hessens. Zweite Folge. Botanik und Naturschutz in Hessen 23, 89-110.

Furlan, D., 1977: The climate of Southeast Europe. In: WallÉn, C. C. (ed.), World Survey of Climatology 6: Climates of Central and Southern Europe, 185-223. Elsevier, Amsterdam, Oxford, New York.

GIORDANI, P., 2007: Is the diversity of epiphytic lichens a reliable indicator of air pollution? A case study from Italy. Environmental Pollution 146, 317-323.

GioRDANI, P., 2012: Assessing the effects of forest management on epiphytic lichens in coppiced forests using different indicators. Plant Systems - DOI:10.1080/11263504. 2011.654136.

Giordani, P., Brunialti, G., Benesperi, R., Rizzi, G., Frati, L., Modenesi, P., 2009: Rapid biodiversity assessment in lichen diversity surveys: implications for quality assurance. Journal of Environmental Monitoring 11, 730-735.

Gondard, H., Romane, F., SAnta Regina, I., LeOnARdi, S., 2006: Forest management and plant species diversity in chestnut stands of three Mediterranean areas. Biodiversity and Conservation 15, 1129-1142. 
Hafellner, J., Obermayer, W., 2007: Flechten und lichenicole Pilze im Gebiet der Stubalpe (Österreich, Steiermark und Kärnten). Mitteilungen des Naturwissenschaftlichen Vereins für Steiermark 136, 5-59.

Heininger, C., Spribille, T., 2009: The sorediate species of Xylographa in Austria (Baeomycetales, lichenized Ascomycetes). Herzogia 22, 129-134.

Holien, H., Tønsberg, T., 2008: Xylographa soralifera, a new species in the $X$. vitiligo complex. Graphis Scripta 20, 58-63.

Jørgensen, P. M., 1978: The lichen family Pannariaceae in Europe. Opera Botanica 45, $1-123$.

KneŽEvić, B., MAYrhofer, H., 2009: Catalogue of the lichenized and lichenicolous fungi of Montenegro. Phyton 48, 283-328.

KuKwa, M., 2008: Monodictys epilepraria, a lichenicolous fungus new to Slovenia. Herzogia 21, 233-234.

KuKWA, M., Diederich, P., 2005: Monodictys epilepraria, a new species of lichenicolous hyphomycetes on Lepraria. Lichenologist 37, 217-220.

KušAn, F., 1953: Catalogue of lichens of Yugoslavia (In Croatian). Jugoslavenska Akademija znanosti i umjetnosti, Zagreb.

Lindacher, R., Pietschmann, M., 1990: Altersstadien moosreicher Vegetation auf Castanea sativa in Elba. Herzogia 8, 383-401.

LopPI, S., BonINI, I., 2000: Lichens and mosses as biomonitors of trace elements in areas with thermal springs and fumarole activity (Mt. Amiata, central Italy). Chemosphere 41, 1333-1336.

LopPI, S., NAscimbene, J., 1998: Lichen bioindication of air quality in the Mt. Amiata geothermal area (Tuscany, Italy). Geothermics 27, 295-304.

Loppi, S., Putortí, E., DE Dominicis, V., 1997: Florula lichenica epifita di un Castagneto (Montieri, Toscana). Atti del Museo di Storia Naturale della Maremma 16, 85-90.

Matteucci, E., Benesperi, R., Giordani, P., Piervittori, R., Isocrono, D., 2012: Epiphytic lichen communities in chestnut stands in Central-North Italy. Biologia 67, 61-70.

Matteucci, E., Isocrono, D., Piervittori, R., 2010: Epiphytic lichen diversity in chestnut woods. Acta Horticulturae 1, 65-72.

Nascimbene, J., Nimis, P. L., RAVERA, S., 2013: Evaluating the conservation status of epiphytic lichens of Italy: A red list. Plant Biosytems, DOI: 10.1080/11263504.2012. 748101 .

Nimis, P. L., MARTEllos, S., 2008: ITALIC - The information system on Italian lichens. Version 4.0. University of Trieste, Dept. of Biology. Retrieved Aprile 4, 2013 from http://dbiodbs.univ-trieste.it/

Orange, A., James, P. W., White, F. J., 2010: Microchemical methods for the identification of lichens. British Lichen Society, London.

PoElT, J., 1969: Bestimmungsschlüssel europäischer Flechten. J. Cramer, Lehre.

PoELT, J., VĚZDA, A., 1977: Bestimmungsschlüssel europäischer Flechten. Ergänzungsheft I. Bibliotheca Lichenologica 9, 1-258. 
Mayrhofer H., Drescher A., SteŠEvić D., Bilovitz P. O.

Poelt, J., VĚZDA, A., 1981: Bestimmungsschlüssel europäischer Flechten. Ergänzungsheft II. Bibliotheca Lichenologica 16, 1-390.

Roth, I., Scheidegger, C., 1997: Die Edelkastanie als Lebensraum für epiphytische Flechten. Bündnerwald 3, 59-68.

SchiEfElBein, U., 2013: Additions to the lichenized and lichenicolous fungi of Mecklenburg-Western Pomerania (Germany). Herzogia 26, in press.

Šoun, J., Vondrák, J., Søchting, U., HrouzeK, P., Khodosovtsev, A., Arup, U., 2011: Taxonomy and phylogeny of the Caloplaca cerina group in Europe. Lichenologist 43, $113-$ 135.

SuiJA, A., JÜRIAdO, I., LEPPIK, E., RANDlANE, T., 2006: New Estonian records. New lichens and lichenicolous fungi. Folia Cryptogamica Estonica 42, 103-105.

Suppan, U., Prügger, J., Mayrhofer, H., 2000: Catalogue of the lichenized and lichenicolous fungi of Slovenia. Bibliotheca Lichenologica 76, 1-215.

Tretiach, M., Ganis, P., 1999: Hydrogen sulphide and epiphytic lichen vegetation: A case study on Mt. Amiata (Central Italy). Lichenologist 31, 163-181.

VĚZDA, A., 1968: Lichenes selecti exsiccate. Fasc. XXIX (no. 701-725). Instituto Botanico Academiae Scientiarum Čechoslovacae, Průhonice prope Pragam.

VĚZDA, A., 1971: Lichenes selecti exsiccate. Fasc. XXXIX (no. 951-975). Instituto Botanico Academiae Scientiarum Čechoslovacae, Průhonice prope Pragam.

VondrÁK, J., Šoun, J., Redchenko, O., LöKÖS, L., Khodosovtsev, A., 2009: Populations of two Caloplaca species with peculiar ecology observed in the Bükk Mts, Hungary. Bryonora 44, 8-12.

White, F. J., JAMES, P. W., 1985: A new guide to microchemical techniques for the identification of lichen substances. Bulletin of the British Lichen Society 57 (Suppl.), 1-41.

WIRTH, V., 1995: Flechtenflora. Bestimmung und ökologische Kennzeichnung der Flechten Südwestdeutschlands und angrenzender Gebiete. Ulmer, Stuttgart.

WIRTH, V., 2010: Ökologische Zeigerwerte von Flechten - erweiterte und aktualisierte Fassung. Herzogia 23, 229-248. 